\title{
PEMBANGUNAN PROTOTYPE SISTEM INFORMASI ADMINISTRASI KEPENDUDUKAN BERBASIS DATA TERDISTRIBUSI
}

\author{
Muh. Abdur Rohman, Beta Noranita, Djalal Er Riyanto, dan Adi Wibowo \\ Program Studi Ilmu Komputer, Fakultas Matematika dan Ilmu Pengetahuan Alam, Universitas \\ Diponegoro, Jalan Proef. Soedarto, SH, Tembalang Semarang, 50275, Indonesia \\ E-mail: beth2nice@yahoo.com
}

\begin{abstract}
Abstrak
Data kependudukan merupakan suatu hal yang harus dikelola oleh pemerintah, baik daerah maupun pusat. Mekanisme pendataan yang disimpan pada masing-masing daerah dan tidak adanya komunikasi yang menyinkronkan data menyebabkan pencatatan ganda NIK. Sistem basis data terdistribusi merupakan kumpulan basis data yang tersebar di dua komputer atau lebih yang terhubung dalam jaringan komputer. Sistem basis data terdistribusi memberikan keuntungan ketersediaan data serta otonomi dalam pengelolaan data pada masing-masing lokal. Metode basis data terdistribusi yang digunakan adalah metode fragmentasi horizontal. Rancangan basis data terdistribusi data kependudukan dapat digunakan untuk mencegah pencatatan ganda NIK. Prototype Sistem Informasi Administrasi Kependudukan Berbasis Data Terdistribusi (SIAK BDT) yang dibuat digunakan untuk melakukan manajemen data kependudukan seperti menambah, mengubah, dan menampilkan data kependudukan dari berbagai lokasi yang berbeda, serta ketersediaan data. Pengujian terhadap prototype SIAK BDT dilakukan dengan metode simulasi. Dari hasil pengujiannya, prototype SIAK BDT mampu melakukan manajemen data penduduk dari berbagai lokasi yang berbeda dan ketersediaan data.
\end{abstract}

Kata Kunci: nomor induk kependudukan (NIK), sistem informasi administrasi kependudukan (SIAK), basis data terdistribusi (BDT)

\begin{abstract}
Population data is a matter that must be managed should the government, either local or central. Data collection mechanism that is stored in each region and the lack of communication led to record multiple data sync NIK. Distributed database system is a collection of databases that are spread across two or more computers connected in a network computer. Distributed database systems provide the advantage of data availability as well as autonomy in the management of data on each local. Distributed database methods used are horizontal fragmentation method. The design of distributed database population data can be used to prevent double registration of NIK. Prototype of Sistem Informasi Administrasi Kependudukan Berbasis Data Terdistribusi (SIAK BDT) made is used to perform demographic data management such as adding, changing, and displaying population data from a variety of different locations, and availability of data. Prototype testing of SIAK BDT performed by the method of simulation. From the test results, prototype SIAK BDT able to perform data management people from many different locations and availability of data.
\end{abstract}

Keywords: nomor induk kependudukan (NIK), sistem informasi administrasi kependudukan (SIAK), basis data terdistribusi (BDT)

\section{Pendahuluan}

Data kependudukan merupakan suatu hal yang harus dikelola baik oleh pemerintah, baik daerah maupun pusat. Keberadaaan datanya pun dituntut untuk selalu up to date (saat ini). Salah satu bentuk akibat tidak up to date-nya data kependudukan adalah kasus Daftar Pemilih Tetap (DPT) pada Pemilihan Umum 2009. Terdapat penduduk yang tidak dapat menggunakan hak pilihnya karena belum terdaftar. Metode sensus dan survei akan menghabiskan waktu dan biaya karena petugas harus secara berkala mendata penduduk [1].

Sesuai dengan Peraturan Pemerintah (PP) Republik Indonesia Nomor 37 Tahun 2007 Tentang Pelaksanaan Undang-Undang Nomor 23 Tahun $2006 \quad$ Tentang Administrasi Kependudukan, Pemerintah Indonesia dalam hal ini Departemen Dalam Negeri telah memutuskan 
penerbitan Nomor Induk Kependudukan (NIK) sebagai nomor identitas Penduduk Indonesia yang bersifat unik atau khas, tunggal dan melekat pada seseorang yang terdaftar sebagai Penduduk Indonesia dan berkaitan secara langsung dengan seluruh Dokumen Kependudukan [2][3].

Sesuai dengan PP Nomor 37 tahun 2007, data kependudukan akan dikelola dengan menggunakan Sistem Informasi Administrasi Kependudukan (SIAK). Pengelolaan SIAK saat ini ditempatkan pada masing-masing kabupaten. Komunikasi SIAK antarkabupaten belum terhubung dalam jaringan komputer. Hal ini dapat menyebabkan terjadinya pencatatan ganda seperti, satu penduduk dapat memiliki lebih dari satu NIK atau satu NIK dapat dimiliki oleh lebih dari satu penduduk [3].

Perkembangan teknologi jaringan komputer yang membuat komunikasi data semakin mudah. Hal tersebut mendorong evolusi sistem basis data, yang semula terpusat menjadi terdistribusi. Sistem basis data terdistribusi adalah sebuah sistem basis data yang disimpan di dalam lebih dari satu komputer pada lokasi yang berlainan dan masingmasing lokal terhubung dengan jaringan komputer [4].

Sistem basis data terdistribusi memberikan beberapa keuntungan. Keuntungannya antara lain kemampuan dalam menangani ekspansi (peningkatan atau perluasan) volume data dan ketersediaan data, serta otonomi dalam pengelolaan data pada masing-masing lokal [5].

Berdasarkan latar belakang tersebut maka akan diteliti mengenai penerapan basis data terdistribusi pada prototype Sistem Informasi Administrasi Kependudukan.

Paper ini membahas suatu teknik baru mengenai penerapan basis data terdistribusi pada prototype Sistem Informasi Administrasi Kependudukan. Selanjutnya dilakukan simulasi untuk menguji kemampuan prototye tersebut.

Sesuai dengan UU Nomor 23 Tahun 2006 Tentang Administrasi Kependudukan, SIAK adalah sistem informasi yang memanfaatkan teknologi informasi dan komunikasi untuk memfasilitasi pengelolaan informasi administrasi kependudukan di tingkat Penyelenggara dan Instansi Pelaksana sebagai satu kesatuan. Penyimpanan basis data SIAK atau data center sekarang ini dilakukan terpisah di masing-masing kabupaten. Akan tetapi karena tidak adanya komunikasi yang menyinkronkan data antarkabupaten sering menimbulkan terjadinya pencatatan ganda. Misalnya, satu penduduk dapat memilki NIK lebih dari satu. Tentu hal ini tidak sesuai dengan UU Nomor 23 Tahun 2006 PP nomor 37 tahun 2007 yang disebutkan bahwa NIK sebagai nomor identitas Penduduk Indonesia yang bersifat unik atau khas, tunggal dan melekat pada seseorang [2][3].

Masalah lain yang sering terjadi adalah satu NIK dapat dimiliki oleh lebih dari satu penduduk. Hal tersebut dikarenakan NIK dan data kependudukan yang disimpan di kabupaten asal akan dihapus ketika terjadinya perpindahan penduduk. Penghapusan NIK tentu sangat berpengaruh terhadap pencatatan NIK baru di kabupaten asal. Selanjutnya kabupaten tujuan harus memasukkan data baru yang berasal dari kabupaten asal.

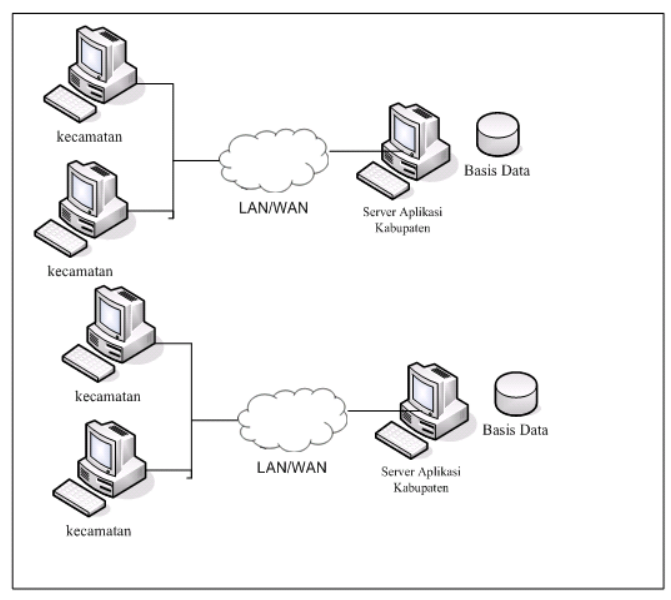

Gambar 1. Perspektif sistem saat ini.

Selain itu dalam pelaporan ke Instansi Pelaksana tingkat provinsi atau pusat belum ideal. Hal tersebut dikarenakan pengiriman data dilakukan secara berkala oleh Instansi Pelaksana kabupaten. Sehingga Instansi Pelaksana tingkat provinsi atau pusat harus menunggu kiriman data penduduk dan mengumpulkan menjadi satu.

Pada gambar 1 dapat dilihat bahwa komunikasi data antarkabupaten belum ada. Program SIAK dan basis datanya berada di kabupaten masing-masing. Masing-masing kabupaten berdiri sendiri dan hanya dapat diakses oleh pengguna di tingkat kecamatan dan kabupaten (Instansi Pelaksana). Ketika Administrasi Kependudukan tingkat provinsi atau pusat membutuhkan data, maka Instansi Pelaksana akan mengirim data penduduk secara manual melalui email (bentuk softcopy) atau printout (bentuk hardcopy).

Aturan yang dianut dalam Administrasi Kependudukan adalah UU No 23 Tahun 2006 Tentang Administrasi Kependudukan dan PP No 
37 Tahun 2007 Tentang UU No 23 Tahun 2006 Tentang Administrasi Kependudukan. Beberapa aturan yang dianut dalam prototype SIAK BDT ini yaitu, (1) setiap penduduk memiliki sebuah NIK yang bersifat unik dan khas. (UU No 23 Tahun 2006 Pasal 1); (2) NIK berlaku seumur hidup dan selamanya, tidak berubah dan tidak mengikuti perubahan domisili.(PP No 37 Tahun 2007 Pasal 38); (3) penduduk Warga Negara Indonesia dan Orang Asing yang memiliki Izin Tinggal Tetap hanya diperbolehkan terdaftar dalam 1 (satu) KK. (UU No 23 Tahun 2006 Pasal 62 ayat 1); (4) nomor KK berlaku untuk selamanya. Nomor KK baru akan diterbitkan jika terjadi perubahan kepala keluarga. (UU No 23 Tahun 2006 Pasal 61 ayat 3); (5) sebuah Kartu Keluarga (KK) wajib memiliki kepala keluarga.(minimal satu anggota yakni kepala keluarga itu sendiri) (Penjelasan UU No 23 Tahun 2006 Pasal 61 ayat 1); (6) perubahan susunan keluarga dalam $\mathrm{KK}$ adalah perubahan yang diakibatkan adanya Peristiwa Kependudukan atau Peristiwa Penting seperti pindah datang, kelahiran, atau kematian. (Penjelasan UU No 23 Tahun 2006 Pasal 62 ayat 2); (7) penduduk yang meninggal dan pindah akan kehilangan keanggotaan $\mathrm{KK}$ di $\mathrm{KK}$ asal atau lama; (8) penduduk datang dapat didaftarkan pada KK lama atau membuat KK baru pada tempat tujuan datang.

Basis data terdistribusi adalah sistem basis data yang difragmentasi atau direplikasi pada beberapa konfigurasi perangkat keras dan lunak yang ditempatkan pada lokasi yang berbeda-beda dalam sebuah organisasi [4].

Basis data terdistribusi juga didefinisikan sebagai sejumlah site yang saling berhubungan via jaringan komputer yang masing-masing memiliki sistem basis data penuh dalam kewenangannya sendiri tetapi masing-masing site setuju untuk bekerja sama [6].

Basis data terdistribusi merupakan sekumpulan beberapa basis data yang secara logika saling terkait dan terdistribusi melalui jaringan komputer [5].

Basis data terdistribusi adalah basis data yang disebarkan pada sejumlah lokasi [7]. Setiap lokasi tersebut memiliki kewenangan sendiri dalam mengelola basis data. Masing-masing lokasi bisa melakukan transaksi lokal dan global. Transaksi lokal adalah transaksi yang dilakukan pada satu lokasi saja. Sedangkan transaksi global adalah transaksi yang membutuhkan kerjasama dan komunikasi beberapa lokasi.
Dari definisi di atas dapat didefinisikan bahwa basis data terdistribusi adalah sekumpulan basis data yang disimpan dalam komputer yang berlokasi berbeda-beda dengan kewenangan masing-masing (otonomi lokal) yang terhubung dalam jaringan komputer.

Basis data terdistribusi memiliki beberapa keuntungan [5] yaitu meningkatkan kinerja, karena setiap site menangani hanya bagian dari basis data, CPU dan I/O tidak seberat seperti basis data terpusat. Kinerja lebih baik karena data yang disimpan setiap site-nya menjadi lebih kecil. Kemudian dapat meningkatkan reliabilitas dan ketersediaan data. Jika data dari satu site mengalami kegagalan, site yang lain masih dapat diakses.

Sehingga tidak seluruh sistem yang mengalami kegagalan. Lebih baik lagi jika data direplikasi ke banyak site, maka sistem masih tetap akan berjalan, meskipun terdapat site yang gagal. Memudahkan expansion (perluasan) karena pada lingkungan terdistribusi, perluasan sistem dalam penambahan data, penambahan ukuran basis data dan penyimpanannya menjadi lebih mudah. Selain itu memberikan keuntungan yaitu otonomi lokal karena data didistribusikan, user dapat mengakses dan bekerja dengan data tersebut sehingga memiliki kontrol lokal.

Arsitektur basis data terdistribusi dapat dilihat pada gambar 2. Pemakai melakukan untuk meminta layanan data (query or transaction program). Melalui program yang digunakan pemakai (request interface), transaksi tersebut diteruskan ke DDBMS yang di dalamnya terdapat sekumpulan program yang beroperasi pada komputer yang berbeda (node $\mathrm{x}, \mathrm{y}, \mathrm{z}$ ), yaitu DTM (Distributed Transaction Manager), DBM (Distributed Database Manager) dan action interface.

Permintaan layanan data dari pemakai, pertama kali diterima oleh DTM. Permintaan data dari pemakai akan diterjemahkan dan diubah menjadi perintah yang dapat dikerjakan (action interface) oleh beberapa DBM. DBM merupakan program yang digunakan untuk mengolah beberapa bagian dari basis data yang telah didistribusikan. Proses di dalam DBM meliputi operasi pengambilan data maupun operasi peremajaan data, tergantung dari perintah yang dikirimkan oleh DTM.

Setelah operasi pengambilan data atau peremajaan data yang terjadi di dalam DBM selesai, layanan data yang diminta akan dikirim kembali ke DTM. DTM akan meneruskan ke user request interface, selanjutnya akan dikirim ke pemakai. 


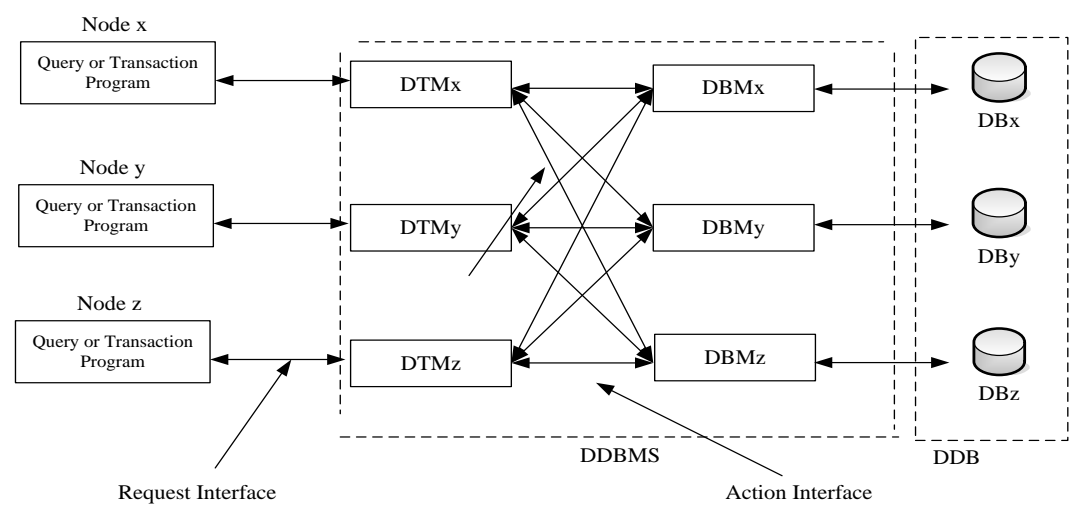

Gambar 2. Arsitektur basis data terdistribusi [8]

Dalam basis data terdistribusi, basis data dikelola oleh SMBD server yang terdapat dalam komputer secara terpisah. Dalam hal ini dimungkinkan terjadi penggunaan SMBD server yang sama dan berbeda. Untuk penggunaan SMBD yang sama disebut homogen. Sedangkan penggunaan penggunaan SMBD yang berbeda disebut heterogen. Pada tipe heterogen, struktur dari basis data haruslah sama. Dalam merancang basis data terdistribusi terdapat dua pendekatan, yakni replikasi dan fragmentasi [7].

\section{Metodologi}

Pada penelitian dalam membangun prototype tersebut dilakukan dengan beberapa langkah. Langkah pertama yaitu analisis kebutuhan. Di mana analisis sistem adalah penguraian dari suatu sistem informasi yang utuh ke dalam bagianbagian komponennya dengan maksud untuk mengidentifikasikan dan mengevaluasi permasalahan-permasalahan, kesempatankesempatan, hambatan-hambatan yang terjadi dan kebutuhan-kebutuhan yang diharapkan sehingga dapat diusulkan perbaikan-perbaikannya[9]. Tahap analisis meliputi pemodelan data dan pemodelan fungsional.

Langkah kedua yaitu rancangan perangkat lunak di mana proses perancangan sistem membagi persyaratan dalam sistem perangkat keras atau perangkat lunak. Kegiatan ini menentukan arsitektur sistem secara keseluruhan. Perancangan perangkat lunak melibatkan identifikasi dan deskripsi abstraksi sistem perangkat lunak yang mendasar dan hubunganhubungannya[10].

Sebagaimana persyaratan, desain didokumentasikan dan menjadi bagian dari konfigurasi perangkat lunak [11]. Tahap desain meliputi perancangan data, perancangan fungsional, dan perancangan antarmuka. Langkah ketiga yaitu implementasi prototype di mana desain harus diterjemahkan ke dalam bentuk mesin yang dapat dibaca. Langkah pembuatan kode melakukan tugas ini. Jika desain dilakukan dengan cara yang lengkap, pembuatan kode dapat diselesaikan secara mekanis [11].

Langkah keempat yaitu pengujian prototype di mana pengujian perangkat lunak adalah elemen kritis dari jaminan kualitas perangkat lunak dan merepresentasikan kajian pokok dari spesifikasi, rancangan, dan pengkodean[11]. Terdapat dua metode pengujian yaitu metode whiteboxdan blackbox. Metode whitebox yaitu pengujian yang berfokus pada logika internal perangkat lunak (sourcecodeprogram). Sedangkan metode blackbox yaitu mengarahkan pengujian untuk menemukan kesalahan-kesalahan dan memastikan bahwa input yang dibatasi akan memberikan hasil aktual yang sesuai dengan hasil yang dibutuhkan

Pada pengujian ini penulis melakukan dengan cara blackbox yaitu menguji fungsionalitas dari perangkat lunak saja tanpa harus mengetahui struktur internal program (source code).

\section{Hasil dan Pembahasan}

Analisis kebutuhan. Pada gambar 3 dapat dilihat bahwa komunikasi data dirancang antar kecamatan. Masing-masing kecamatan menyimpan basis data kecamatannya. Basis data tersebut memiliki interkoneksi LAN/WAN dengan Server Prototype SIAK BDT yang berada di Administrasi Kependudukan Pusat. Prototype dikoneksikan internet yang dapat diakses oleh pengguna seperti kecamatan, instansi pelaksana (kabupaten), provinsi, atau pusat.

Spesifikasi kebutuhan perangkat lunak dapat dilihat pada tabel I. Data yang digunakan dalam sistem ini sesuai dengan data yangdigunakan pada UD. JATI NUGROHO. Bagian ini akan dijelaskan ERD, dan DFD (gambar 5), yang akan digunakan untuk pengembangan sistem. 


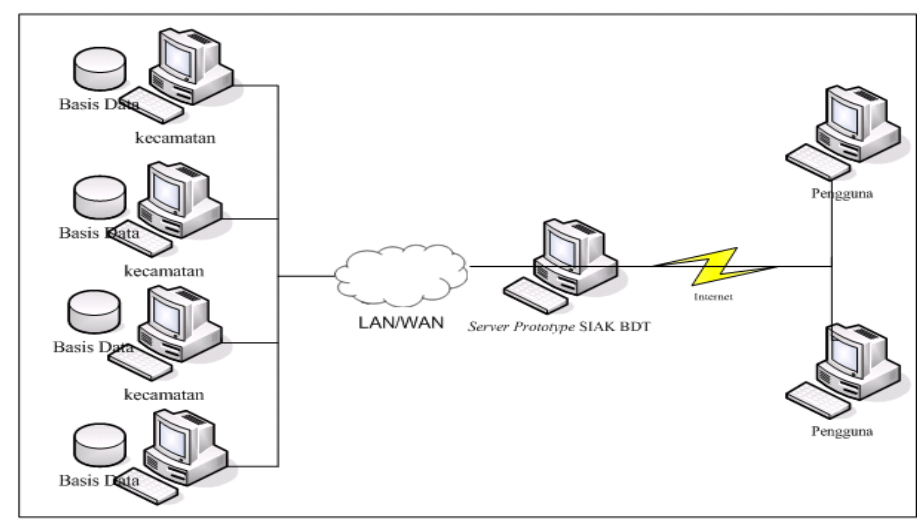

Gambar 3. Perspektif sistem yang akan dibangun.

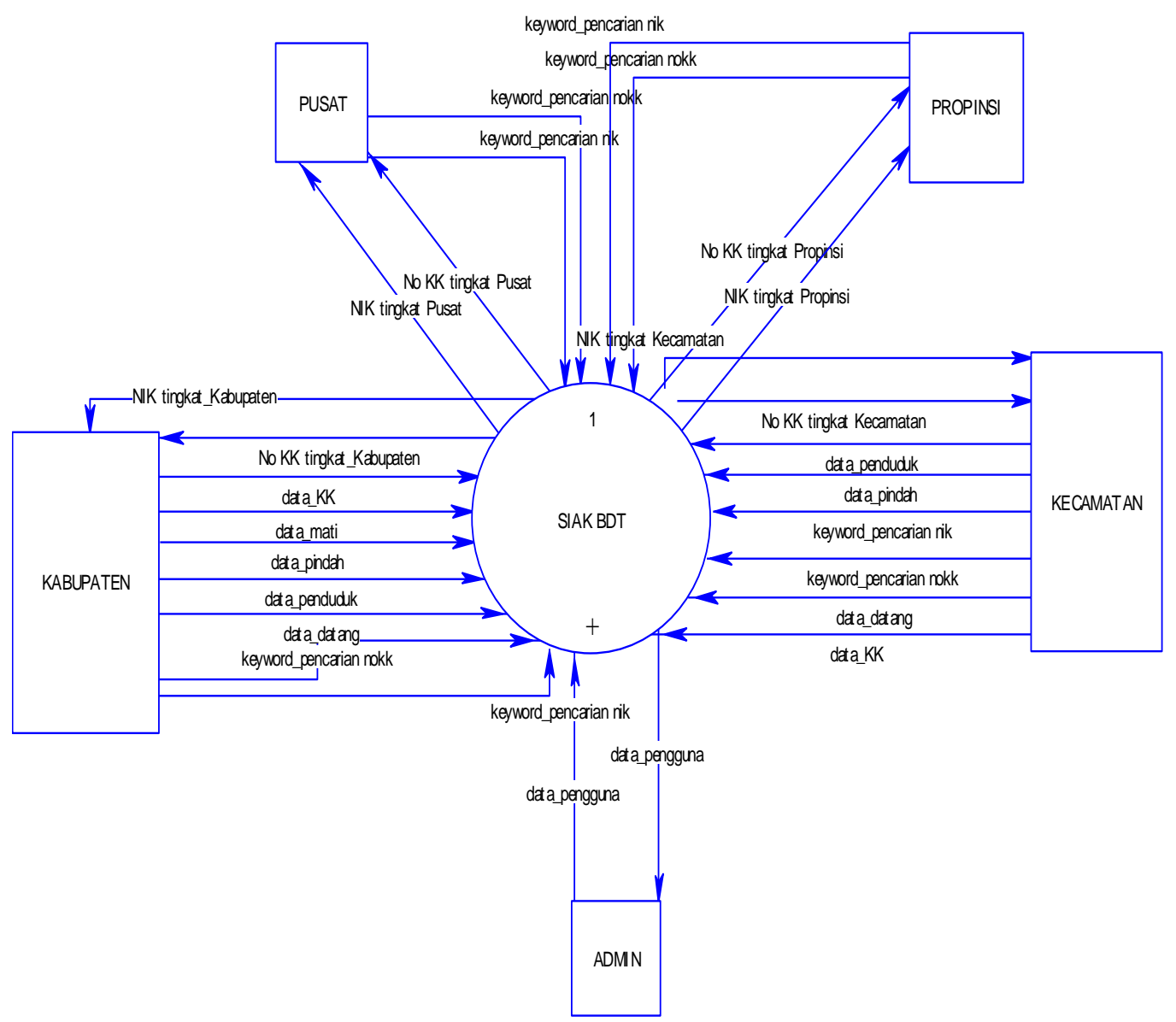

Gambar 4. DCD.

DCD yang digambarkan pada gambar 4 terdapat lima External Entity yakni kecamatan, kabupaten, provinsi, pusat, serta admin. Semua External Entity mengakses pada satu proses,yakni SIAK BDT. Rancangan Perangkat Lunak.Pembentukan PDM (Physical Data Model) dilakukan dalam beberapa langkah-langkah. Langkah pertama setiap entitas dijadikan tabel sendiri. Langkah kedua, untuk entitas yang memiliki relasi satu ke satu yaitu derajat minimum sama, dibuat dua tabel dan atribut pada relasi dileburkan pada entitas yang dimungkinkan memiliki pertumbuhan (jumlah data) kecil dan untuk derajat minimum berbeda dibuat dua tabel dan atribut pada relasi dileburkan pada entitas yang dimungkinkan memiliki derajat minimum terbesar. 
Langkah ketiga untuk entitas yang memiliki relasi satu ke banyak, dibuat dua tabel dan atribut pada relasi dileburkan pada entitas yang memiliki kardinalitas N. Langkah keempat untuk entitas yang memiliki relasi banyak ke banyak, entitas menjadi tabel sendiri-sendiri dan relasi menjadi tabel tersendiri. Sehingga hasil mapping dari ERD ke PDM dapat dilihat pada gambar 6.

Fungsi dirancang berdasarkan spesifikasi kebutuhan yang telah dibuat sebelumnya. Kerunutan antara kebutuhan perangkat lunak dan rancangan fungsi dapat dilihat pada tabel II. Rancangan antarmuka prototype SIAK BDT meliputi rancangan antarmuka login, antarmuka menu pusat, menu provinsi, menu kabupaten, menu kecamatan, menu admin, antarmuka Form NIK Baru dan nomor KK Baru, Form NIK Baru dan nomor KK Lama, Form Cari NIK, Form Edit
Data Penduduk, Form Cari KK, Form Edit Data KK, Form Buat KK Baru, Form Daftar KK Lama, Form Pindah, dan Form Catat Kematian.

Implementasi Prototype SIAK BDT. Sesuai rancangan prototype SIAK BDT yang telah dibuat, selanjutnya adalah implementasi rancangan data, fungsi, dan antarmuka. Lingkungan perangkat lunak dan perangkat keras yang digunakan untuk membangun sistem KRS Online ini adalah sebagai berikut yaitu, CPU dengan Intel Pentium Dual Core $1.8 \mathrm{GHz}$, RAM 2.0 GB. Sistemoperasi dengan Microsoft Windows XP Service Pack 2.Editor Script dengan Notepad++ v5.0.3.Web Browser dengan IE Version 6.0, Mozilla Firefox Version 3.5. DBMS dengan MySQL versión 5.1.30. Web Server dengan xampp-win32-1.7.1.

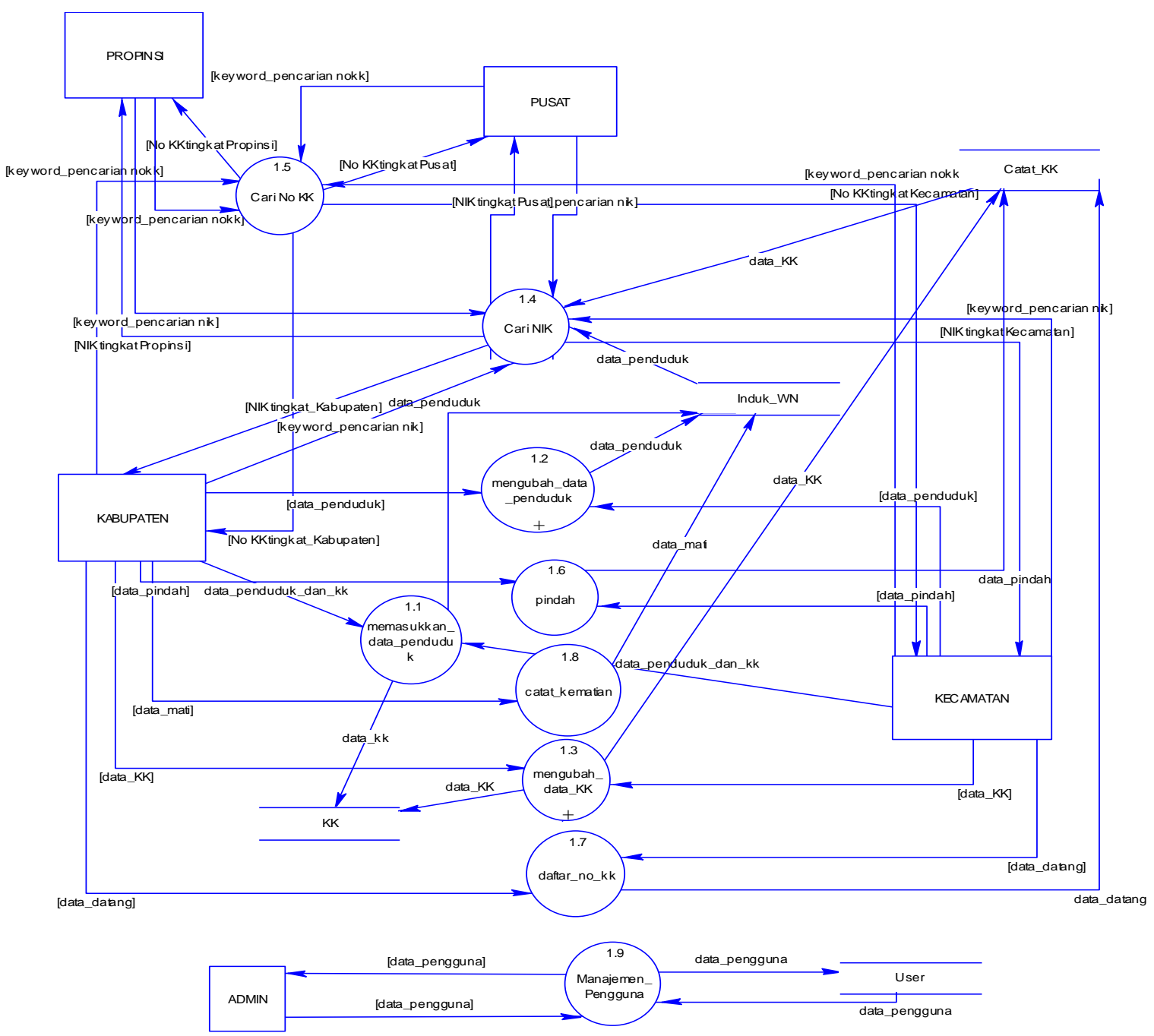

Gambar 5. DFD level 1. 


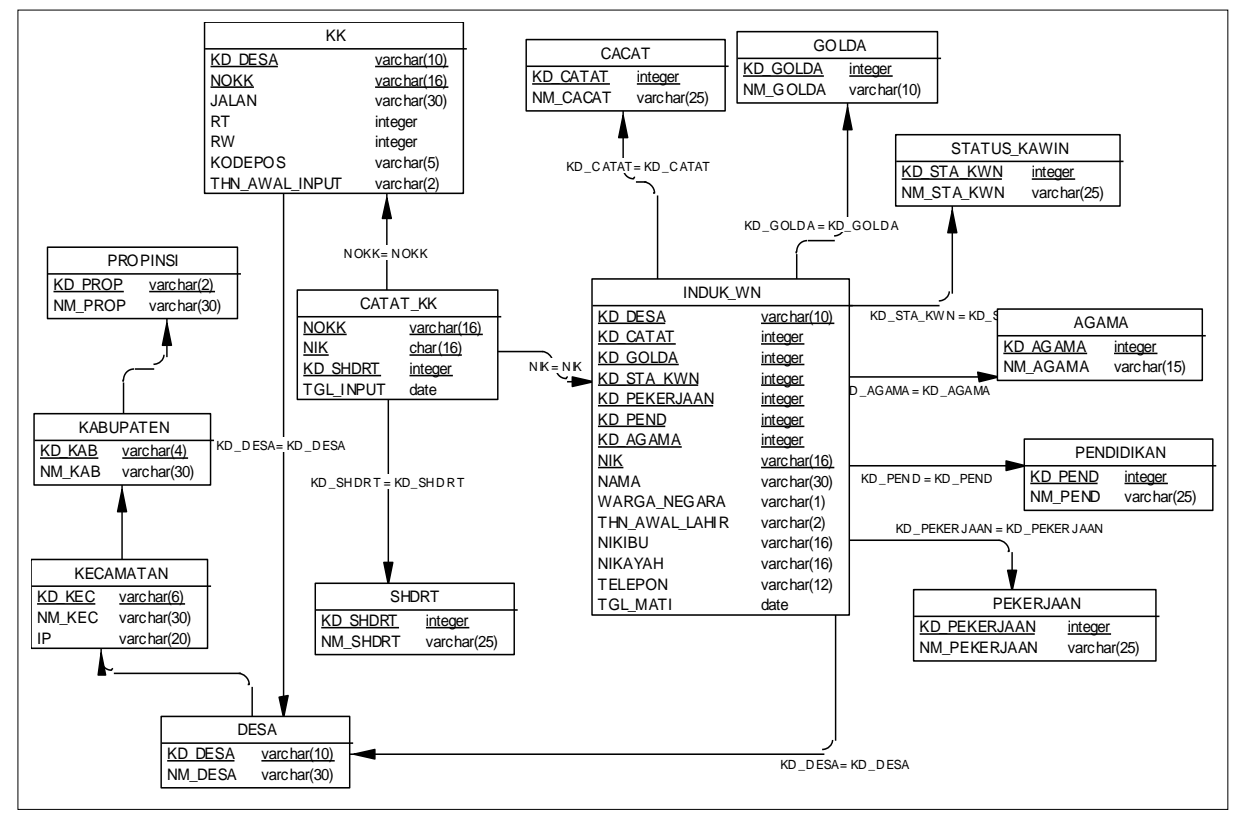

Gambar 6. PDM.

TABEL I

SPESIFIKASI KeBUTUHAN PERANGKAT LUNAK

\begin{tabular}{|c|c|c|c|c|}
\hline \multicolumn{2}{|c|}{ Srs id } & \multicolumn{2}{|c|}{ Nomor fungsi } & Deskripsi \\
\hline $\begin{array}{l}\text { SRS } \\
\text { BDT }\end{array}$ & - & SIAK & F01 & $\begin{array}{llr}\text { Memasukkan } & & \text { data } \\
\text { penduduk } & & \text { untuk } \\
\text { mendapatkan } & \text { NIK } & \text { dan } \\
\text { Nomor KK } & & \end{array}$ \\
\hline $\begin{array}{l}\text { SRS } \\
\text { BDT }\end{array}$ & - & SIAK & F02 & Mengubah data penduduk \\
\hline $\begin{array}{l}\text { SRS } \\
\text { BDT }\end{array}$ & - & SIAK & F03 & Mengubah data KK \\
\hline $\begin{array}{l}\text { SRS } \\
\text { BDT }\end{array}$ & - & SIAK & F04 & Mencari NIK \\
\hline $\begin{array}{l}\text { SRS } \\
\text { BDT }\end{array}$ & - & SIAK & F05 & Mencari Nomor KK \\
\hline $\begin{array}{l}\text { SRS } \\
\text { BDT }\end{array}$ & - & SIAK & F06 & $\begin{array}{l}\text { Mengolah perpindahan } \\
\text { penduduk }\end{array}$ \\
\hline $\begin{array}{l}\text { SRS } \\
\text { BDT }\end{array}$ & - & SIAK & F07 & $\begin{array}{l}\text { Mendaftarkan penduduk } \\
\text { (baik datang maupun tidak } \\
\text { bernomor KK) ke sebuah } \\
\text { Nomor KK }\end{array}$ \\
\hline $\begin{array}{l}\text { SRS } \\
\text { BDT }\end{array}$ & - & SIAK & F08 & $\begin{array}{l}\text { Memasukkan data } \\
\text { kematian }\end{array}$ \\
\hline $\begin{array}{l}\text { SRS } \\
\text { BDT }\end{array}$ & - & SIAK & F09 & $\begin{array}{l}\text { Manajemen data } \\
\text { pengguna prototype SIAK } \\
\text { BDT }\end{array}$ \\
\hline
\end{tabular}

Implementasi rancangan data merupakan transformasi rancangan data yang dihasilkan dari proses perancangan data menjadi suatu basis data. Basis data yang dibangun diberi nama "SIAK CLIENT" dan "SIAK SERVER". Basis data "SIAK_CLIENT" akan ditempatkan pada komputer kecamatan yang berisi dua tabel, yakni tabel Induk_WN dan Catat_KK. Sementara basis data "SIAK_SERVER" ditempatkan pada server aplikasi yang berisi 13tabel yakni tabel Agama, Cacat, Golda, Pekerjaan, Pendidikan, SHDRT, Status_Kawin, Desa, Kecamatan, Kabupaten, dan Provinsi. Penjelasan nama-nama tabel beserta field-field di dalamnya dapat dilihat pada tabel III.

TABEL II

KERUNUTAN KEBUTUHAN DAN RANCANGAN FUNGSI

\begin{tabular}{|c|c|c|c|c|}
\hline $\begin{array}{l}\mathrm{N} \\
\mathrm{O}\end{array}$ & SRS & Deskripsi SRS & $\begin{array}{l}\text { Nomor } \\
\text { fungsi }\end{array}$ & $\begin{array}{l}\text { Nama } \\
\text { fungsi }\end{array}$ \\
\hline 1 & $\begin{array}{l}\text { SRS- } \\
\text { SIAK } \\
\text { BDT-F 01 }\end{array}$ & $\begin{array}{l}\text { Memasukkan } \\
\text { data penduduk } \\
\text { untuk } \\
\text { mendapatkan } \\
\text { NIK dan Nomor } \\
\text { KK }\end{array}$ & 1.1 & $\begin{array}{l}\text { Input Data } \\
\text { Penduduk }\end{array}$ \\
\hline 2 & $\begin{array}{l}\text { SRS- } \\
\text { SIAK } \\
\text { BDT-F } 02\end{array}$ & $\begin{array}{l}\text { Mengubah data } \\
\text { penduduk }\end{array}$ & 2.1 & $\begin{array}{l}\text { Ubah Data } \\
\text { Penduduk }\end{array}$ \\
\hline 3 & $\begin{array}{l}\text { SRS- } \\
\text { SIAK } \\
\text { BDT-F } 03\end{array}$ & $\begin{array}{l}\text { Mengubah data } \\
\text { KK }\end{array}$ & 3.1 & $\begin{array}{l}\text { Ubah Data } \\
\text { KK }\end{array}$ \\
\hline 4 & $\begin{array}{l}\text { SRS- } \\
\text { SIAK } \\
\text { BDT-F } 04\end{array}$ & Mencari NIK & 4.1 & Cari NIK \\
\hline 5 & $\begin{array}{l}\text { SRS- } \\
\text { SIAK } \\
\text { BDT-F } 05\end{array}$ & $\begin{array}{l}\text { Mencari Nomor } \\
\text { KK }\end{array}$ & 5.1 & $\begin{array}{l}\text { Cari nomor } \\
\text { KK }\end{array}$ \\
\hline 6 & $\begin{array}{l}\text { SRS- } \\
\text { SIAK } \\
\text { BDT-F } 06\end{array}$ & $\begin{array}{l}\text { Memroses } \\
\text { perpindahan } \\
\text { penduduk }\end{array}$ & 6.1 & Pindah \\
\hline 7 & $\begin{array}{l}\text { SRS- } \\
\text { SIAK } \\
\text { BDT-F } 07\end{array}$ & $\begin{array}{l}\text { Mendaftarkan } \\
\text { penduduk (baik } \\
\text { datang maupun } \\
\text { tidak bernomor } \\
\text { KK) ke sebuah } \\
\text { Nomor KK }\end{array}$ & 7.1 & $\begin{array}{l}\text { Daftar } \\
\text { nomor KK }\end{array}$ \\
\hline 8 & $\begin{array}{l}\text { SRS- } \\
\text { SIAK } \\
\text { BDT-F } 08\end{array}$ & $\begin{array}{l}\text { Memasukkan } \\
\text { data kematian }\end{array}$ & 8.1 & $\begin{array}{l}\text { Catat } \\
\text { Kematian }\end{array}$ \\
\hline 9 & $\begin{array}{l}\text { SRS- } \\
\text { SIAK } \\
\text { BDT-F } 09\end{array}$ & $\begin{array}{l}\text { Manajemen data } \\
\text { pengguna } \\
\text { prototype SIAK } \\
\text { BDT }\end{array}$ & 9.1 & $\begin{array}{l}\text { Manajeme } \\
\mathrm{n} \text { Data } \\
\text { Pengguna }\end{array}$ \\
\hline
\end{tabular}


Dalam melakukan pengujian Prototype SIAK BDT, ditemukan hambatan teknis yaitu di masing-masing kabupaten belum terhubung dalam jaringan komputer. Padahal, syarat mutlak yang harus dipenuhi dalam pemakaian sistem basis data terdistribusi adalah tersedianya jaringan komputer. Untuk mengatasi permasalahan ini, maka metode yang digunakan dalam pengujian ini adalah simulasi. Metode simulasi merupakan suatu metode yang digunakan untuk membuat seolaholah menyerupai seperti keadaan sebenarnya. Dengan memakai metode simulasi, maka pengujian yang tadinya memerlukan interkoneksi WAN yang digunakan untuk menghubungkan komputer di masing-masing kecamatan bisa digantikan dengan komputer yang berinterkoneksi LAN. Hasil uji coba menggunakan LAN sama dikarenakan baik LAN dan WAN, pada dasarnya sama-sama tersusun atas beberapa elemen dasar yang meliputi komponen fisik (PC, Kartu jaringan, kabel, topologi) serta perangkat lunak (sistem operasi).

Simulasi dilakukan dengan memakai satu unit komputer fisik yang di-install perangkat lunak Sun xVM VirtualBox. Dengan Sun xVM VirtualBox, maka bisa disimulasikan dengan menggunakan enam komputer virtual. Satu unit komputer virtual sebagai Server yang digunakan untuk menyimpan Prototype SIAK BDT. Empat unit komputer virtual sebagai kecamatan yang digunakan untuk menyimpan basis data hasil fragmentasi (Kecamatan Undaan Kabupaten Kudus Jawa Tengah, Kecamatan Kota Kabupaten Kudus Provinsi Jawa Tengah, Kecamatan Mayong Kabupaten Jepara Provinsi Jawa Tengah, Kecamatan Kebayoran Baru Kabupaten Jakarta Selatan Provinsi DKI Jakarta). Satu unit komputer virtual sebagai pengguna yang dapat berotoritas sebagai pusat, provinsi, instansi pelaksana, dan kecamatan. Prototype SIAK BDT disimpan di komputer Server. Rancangan simulasi dapat dilihat pada gambar 7 .

Dalam simulasi ini, digunakan empat unit komputer virtual sebagai kecamatan bertujuan menguji kewenangan hak akses. Misalnya kewenangan pusat akan berhak mengakses data penduduk seluruh kecamatan di Indonesia (Undaan, Kota, Mayong, dan Kebayoran Baru). Kewenangan Provinsi Jawa Tengah berhak mengakses data penduduk kecamatan yang berada di provinsi tersebut (Undaan, Kota, dan Mayong). Kewenangan Instansi Pelaksana di Kabupaten Kudus berhak mengakses data penduduk kecamatan yang berada di kabupaten tersebut (Undaan dan Kota). Kewenangan Kecamatan Undaan hanya berhak mengakses kecamatan Undaan saja.
TABEL III

DAFTAR TABEL DALAM BASIS DATA PROTOTYPE SIAK BDT

\begin{tabular}{|c|c|c|}
\hline Nama tabel & Atribut & $\begin{array}{l}\text { Kunci } \\
\text { utama }\end{array}$ \\
\hline Induk_WN & $\begin{array}{l}\text { nik, nama, } \\
\text { warga_negara, } \\
\text { thn_awal_lahir, nikIbu, } \\
\text { nikAyah, telepon, } \\
\text { tgl_mati, kd_agama, } \\
\text { kd_cacat, kd_golda, } \\
\text { kd_pekerjaan, } \\
\text { kd_pend, kd_sta_kwn, } \\
\text { kd_desa }\end{array}$ & nik \\
\hline KK & $\begin{array}{l}\text { nokk, jalan, rt, rw, } \\
\text { kodepos, } \\
\text { thn_awal_input, } \\
\text { kd_desa }\end{array}$ & nokk \\
\hline Catat_KK & $\begin{array}{l}\text { nokk, nik, tgl_input, } \\
\text { kd_shdrt }\end{array}$ & \\
\hline Agama & $\underline{\text { kd agama, }}$ nm_agama & kd_agama \\
\hline Cacat & kd_cacat, nm_cacat & kd_cacat \\
\hline Golda & $\underline{\mathrm{kd} \text { golda }}, \mathrm{nm}$ _golda & kd_golda \\
\hline Pekerjaan & $\frac{\text { kd_pekerjaan, }}{\text { nm_pekerjaan }}$ & $\begin{array}{l}\text { kd_pekerj } \\
\text { aan }\end{array}$ \\
\hline Pendidikan & kd_pend, nm_pend & kd_pend \\
\hline SHDRT & $\underline{\mathrm{kd} \_s h d r t}, \mathrm{~nm} \_s h d r t$ & kd_shdrt, \\
\hline $\begin{array}{l}\text { Status_Kawi } \\
\mathrm{n} \\
\text { Desa }\end{array}$ & $\begin{array}{l}\text { kd_sta_kwn,nm_sta_k } \\
\text { wn } \\
\underline{\text { kd_desa, }}, n m \_d e s a\end{array}$ & $\begin{array}{l}\text { kd_sta_k } \\
\text { wn } \\
\text { kd_desa }\end{array}$ \\
\hline Kecamatan & $\underline{\mathrm{kd} \text { kec }}, \mathrm{nm} \_\mathrm{kec}$, ip & kd_kec \\
\hline Kabupaten & $\underline{\mathrm{kd} \_k a b}, \mathrm{~nm} \_\mathrm{kab}$ & kd_kab \\
\hline Propinsi & kd_prop, nm_prop & kd_prop \\
\hline
\end{tabular}

Pengujian terhadap penerapan basis data terdistribusi pada basis data kependudukan juga diperlukan. Bentuk pengujian pertama yaitu manajemen data di mana pengguna melakukan pemanggilan Prototype SIAK BDT yang ada di komputer server melalui browser yang ada di komputer client. Pengguna melakukan login pengguna Kabupaten Kudus. Setelah berhasil login, pengguna mencoba melakukan penambahan data penduduk di Kecamatan Undaan. Dalam penambahan ini, server akan menghubungi basis data yang berada di Kecamatan Undaan untuk dilakukan penambahan data. Selanjutnya dicoba pengubahan data penduduk yang berada di Kecamatan Kota. Dalam pengubahan ini, server akan menghubungi basis data yang berada di Kecamatan Kota untuk dilakukan pengubahan data. Kemudian dicoba melakukan permintaan untuk menampilkan penduduk yang bertempat tinggal di Kabupaten Kudus, maka server akan menghubungi basis data yang disimpan di Kecamatan Undaan dan Kota. Gambar 8 menunjukkan mekanisme akses data terdistribusi. 


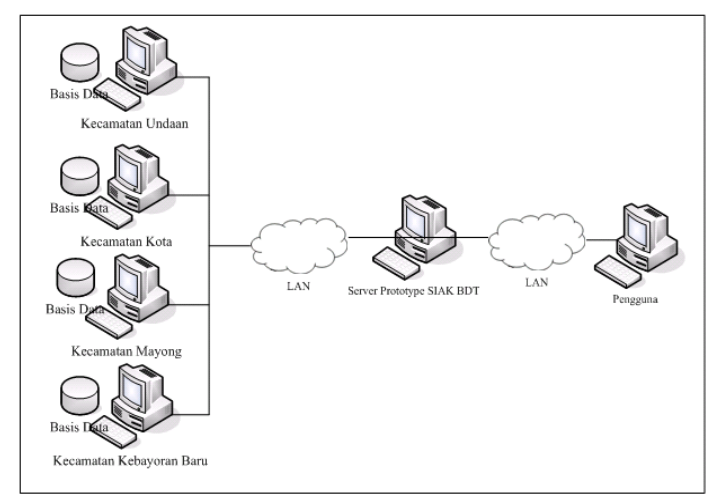

Gambar 7. Rancangan simulasi.
Bentuk pengujian kedua yaitu pengujian ketersediaan data di mana pengguna yang login sebagai pengguna Kabupaten Kudus melakukan pengujian dengan memutus koneksi pada komputer Kecamatan Undaan. Pada komputer ini tersimpan basis data penduduk Kecamatan Undaan. Ketika pengguna ingin melakukan permintaan untuk data penduduk yang bertempat tinggal di Kabupaten Kudus, data yang ada di komputer Kecamatan Undaan tidak dapat ditampilkan, akan tetapi data yang ada di komputer lain (Kecamatan Kota) dapat ditampilkan. Gambar 9 menunjukkan mekanisme akses data saat salah satu koneksi terputus.

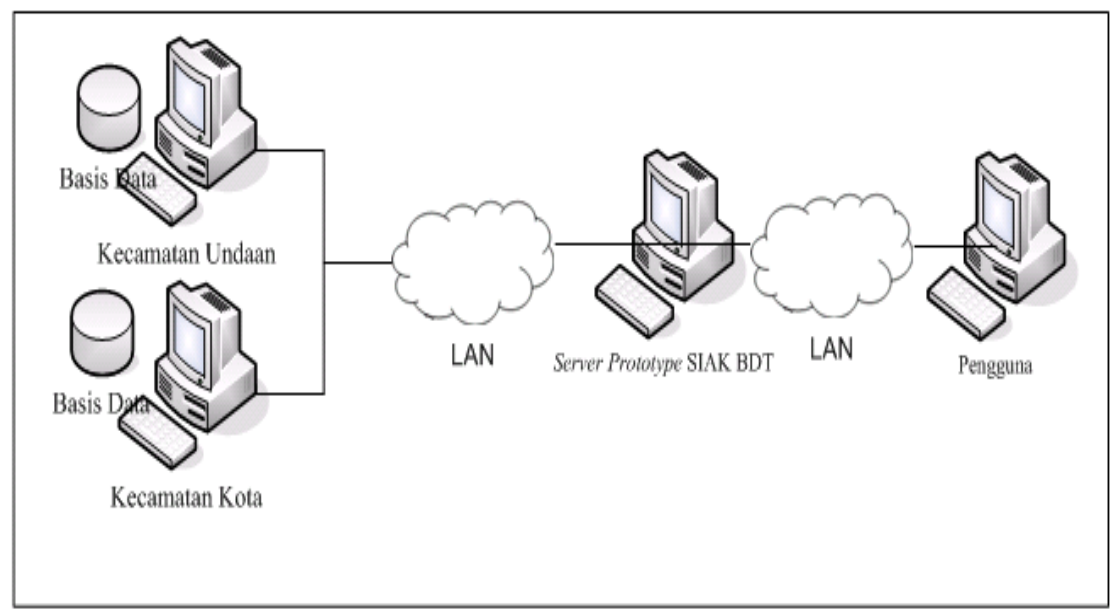

Gambar 8. Mekanisme akses data terdistribusi.

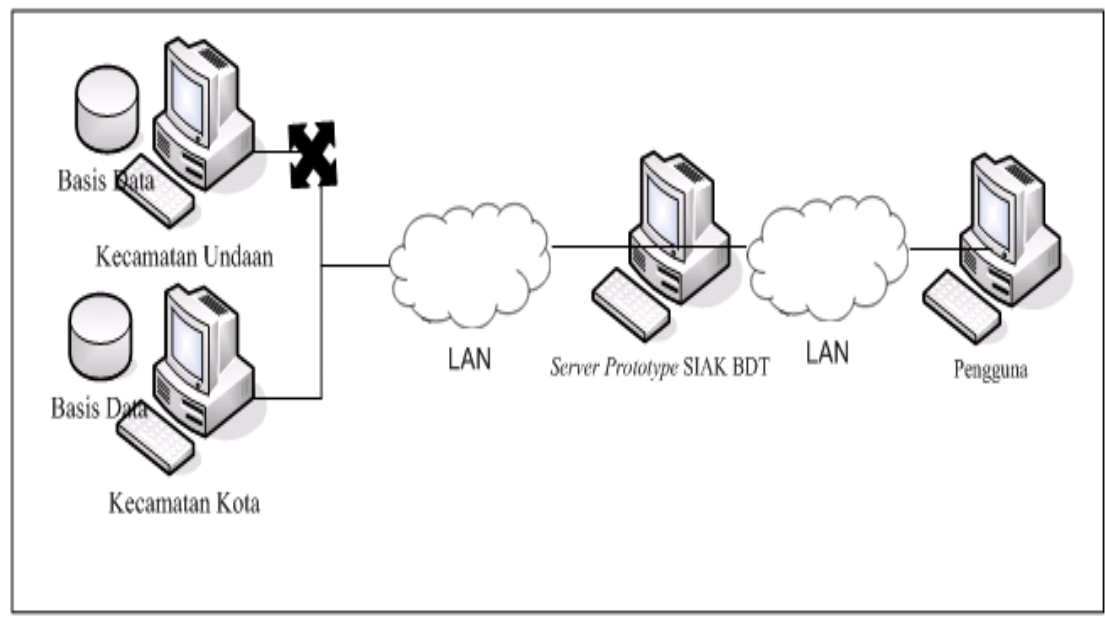

Gambar 9. Mekanisme akses data saat salah satu koneksi putus.

Spesifikasi perangkat keras komputer fisik yaitu processor dengan Intel (R) Pentium Dual Core 1,8 GHz, RAM dengan $2.0 \mathrm{~Gb}$, VGA dengan 32 bit, $256 \mathrm{Mb}$, dan hardisk dengan $80 \mathrm{~GB}$. Sedangkan spesifikasi komputer virtual yaitu Komputer Virtual 1 (Server) dengan RAM 256
Mb dan hardisk3 Gb. Komputer Virtual 2 (Kecamatan Undaan, Kabupaten. Kudus, Provinsi Jawa Tengah) dengan RAM256 Mb dan hardisk: 3 Gb. Komputer Virtual 3 (Kecamatan Kota, Kabupaten.Kudus, Provinsi Jawa Tengah) dengan RAM256 Mb dan hardisk $3 \mathrm{~Gb}$. Komputer Virtual 
4 (Kecamatan Mayong, Kabupaten. Jepara, Provinsi Jawa Tengah) dengan RAM $256 \mathrm{Mb}$ dan hardisk $3 \mathrm{~Gb}$. Komputer Virtual 5 (Kecamatan Kebayoran Baru, Kabupaten. Jakarta Selatan, Provinsi DKI Jakarta) dengan RAM256 Mb dan hardisk3 Gb. Komputer Virtual 6 (Pengguna) dengan RAM $256 \mathrm{Mb}$ dan hardisk $3 \mathrm{~Gb}$

Prototype SIAK BDT diujikan dalam lingkungan perangkat lunak seperti, sistem operasi yang digunakan Microsoft Windows XP dengan hak akses sebagai administrator, prototype SIAK BDT menggunakan PHP script dan HTML, server dan basis data menggunakan xamppwin32-1.7-installer.exe, yang berisi phpMyAdmin 3.1.1, MySQL client version 5.1.30, dan PHP Version 5.2.8, Sun xVMVirtualBox

Pengujian prototype SIAK BDT menggunakan metode black box yang hanya menguji fungsionalitasnya saja. Hasil uji dianggap sukses jika pada tabel pengujian, hasil yang didapat sesuai dengan kriteria evaluasi hasil dan hasil yang diharapkan.

\section{Kesimpulan}

Hasil perancangan basis data terdistribusi NIK dapat digunakan sebagai alternatif pencegahan pencatatan ganda pada NIK dan ketersediaan data tetap terjaga. Sesuai pengujian SRS, Prototype SIAK BDT dapat digunakan untuk melakukan manajemen data kependudukan seperti menambah, mengubah, dan menampilkan data kependudukan dari berbagai lokasi yang berbeda. Untuk meningkatkan kemutakhiran data Prototype SIAK BDT dan peningkatan kinerja pencatatan perkawinan dan perceraian di KUA Kecamatan disarankan dilakukan integrasi data SIAK dengan data yang ada di KUA Kecamatan.

\section{Referensi}

[1] I. Rinaldi, Kasus DPT Ganda di.Mojokerto, Kompas.com,

http://regional.kompas.com/read/2009/03/24/ 20315584/Lagi, 2009, retrieved August 13, 2009.
[2] UNDANG-UNDANG REPUBLIK INDONESIA NOMOR 23 TAHUN 2006 TENTANG ADMINISTRASI KEPENDUDUKAN, Badan Pengawasan Keuangan dan Pembangunan, http://www.bpkp.go.id/unit/hukum/uu/2006/ 23-06.pdf, 2006, retrieved April 30, 2009.

[3] Peraturan Pemerintah Republik Indonesia Nomor 37 Tahun 2007 Tentang Pelaksanaan Undang-Undang Nomor 23 Tahun 2006 Tentang Administrasi Kependudukan, Badan Pengawasan Keuangan dan Pembangunan, http://sms.mahkamahagung.go.id/legislasi/d ocs/PP/PP_2007_37_PELAKSANAAN\%20 UNDANG-

UNDANG\%20NOMOR\%2023\%20TAHUN $\% 202006 \%$ 20TENTANG\%20TENTANG\%2 OADMINISTRASI\%20KEPENDUDUKAN. pdf, 2007, retrieved April 30, 2009.

[4] P.B. Davies, Database Systems, 3rd ed., Palgrave Macmillan, New York, 2004.

[5] Elmasri, Ramez, S.B. Navathe, Fundamentals of Database Systems, 3rd ed., Addison Wesley Publishing Company, New York, 2000.

[6] C.J. Date, An Introduction and Database System, Addison-Wesley, Boston, 2004.

[7] A. Silberschatz, H.F. Korth, S. Sudarshan, Database System Concepts, 4th ed., McGraw-Hill Publishing Company, Boston, 2004.

[8] D.M. Kroenke, Data Processing: Fundamentals, Design, Implementation: International Edition, Pearson, New Jersey, 2005.

[9] H.M. Jogiyanto, Analisis dan Desain Sistem Informasi : Pendekatan Terstruktur Teori dan Praktek Apliktasi Bisnis, Andi, Yogyakarta, 2005.

[10] I. Sommerville, Software Engineering, Erlangga, Jakarta, 2000.

[11] R.S. Pressman, Software Engineering:A Practitioner's Approach, The McGraw-Hill Companies, Inc, New York, 1997. 